\title{
Souvenir in Sentimentalist Topography
}

\author{
Natalia Sipovskaya \\ State Institute for art Studies \\ Moscow, Russia \\ E-mail: sipovskaya@sias.ru
}

\begin{abstract}
The article considers the culture mechanics of Russian Sentimentalism as a non-style phenomenon within the framework of standard aesthetics of the Enlightenment. The author analyses the special pictorial quality of Sentimentalism used to materialise abstract notions and the role of "a souvenir of sentiments" as a landmark on "the memory landscape".
\end{abstract}

Keywords-Sentimentalism; souvenir; memory; Pavlovsk; the Empress Maria Fedorovna; Gavrila R. Derzhavin; Salvatore Tonci

\section{INTRODUCTION}

N.A. Sablukov, one of the most sensitive memoirists of the period of Paul I, directly associated the structures built by Marie Feodorovna in Pavlovsk with her impressions of the trip abroad by the Grand Duke and the Grand Duchess. That was precisely how he explained the appearance of "a rose pavilion reminiscent of that of the Trianon; the chalets similar to those which she had seen in Switzerland; mills and several farms like those of Tirol; ...gardens reminiscent of the gardens and terraces of Italy", as well as of the theatre and the long alleys borrowed from Fontainebleau [1]. This extended quotation is not only homage to Anna Korndorf's report on mnemonic programmes of Russian imperial residences [2]; in fact, the report is about the same phenomenon viewed from a different angle.

Since the personification of memory, just as the personification of feelings and apologia of personal sensitivity (which are perhaps the same thing) were the chief discoveries and meaning of sentimentalist culture, the insistence with which this culture manifested the need for these personified feelings to be visualised directly and virtually embodied cannot be overlooked.

\section{ThE VISUALISATION OF FEELINGS}

Specialists and experts in Russian porcelain in particular have not ignored this characteristic of the culture of the last decade of the $18^{\text {th }}$ century. Gift cups occupied the pride of place in the range of porcelain products (of course, if we count table services as a single unit rather than piece by piece). What is more, there emerged a sort of culture of a porcelain "souvenir of sentiments" [the term was first suggested by M.A. Bubchikova, porcelain keeper of the State Historical Museum (GIM)], in which porcelain cups could be rivalled only by medallions with the portraits of the enamoured or locks of their hair, or else rare (and memorable by dint of their unusualness) embroideries with those locks of hair used as the thread.

Especially impressive are cups with "sentimental inscriptions", such as "dear even when not around" (Imperial Porcelain Factory (IFZ), 1790s; State Museum of Ceramics and Kuskovo Estate (GMK Kuskovo), "cherish to remember" (IFZ,1786-96; State Hermitage), "neither distance nor time can set our hearts apart" (Gardner, 1790s; GIM), "Who shall I gift it to, I asked, and my heart chose you" (Private Factory, 1800s) or "the heart moaning when parted" encrypted in an amusing rebus on a piece from the GIM collection (Gardner, 1790s). Cups decorated with silhouette portraits and emblems of love (quiver, heart and anchor) and just landscapes, in which one can see, alongside memorable places, simple rural sights with strolling figures, the compositions traced back to the engravings from the first Amsterdam edition of Rousseau's The New Heloise, form a far larger group of such items. This list can be continued until we come to things with paintings "eternal" for porcelain that form part of sentimentalist poetics owing to the purpose of the object and the context in which it is presented rather than because of fashionable themes.

A vast range of specimens will be left outside the scope of this report - from cups with views of countryside residences produced in the first five years of the reign of Alexander I as gifts for the Dowager Empress [3] to the "name list" of things that generously adorned palace rooms and pavilions and that were connected with the memory of Marie Feodorovna's native Ludwigsburg, travel impressions and people dear to her heart, and up to the quite imperial set of 14 vases listed in the Dowager Empress' will as "memorabilia" [4] already discussed at length [5].

Let us go back to the main theme. The appearance of a special culture of "souvenir of sentiments" was obviously dictated by the need for tangible tokens of personal "memory of the heart". There are other examples of the visualisation of newly fashionable trends, such as a vogue for artless naturalness, in particular, hairdos decorated with live flowers in the form of an ingenious engineering structure with little flat bottles shaped to the curvature of the head and filled with water to keep flowers fresh. This did not always succeed, as Baroness d'Oberkirch noted with regret when recounting the first testing of that sort of adornment by the Countess du Nord at a reception with the Queen Marie-Antoinette. To make her hairdo look even more natural, "the countess du Nord wore upon her head a little bird made of precious 
stones, so brilliant that no eye could gaze upon it steadily. It was fixed upon a spring; the slightest movement of the wearer put it into motion, when it fluttered its wings above the rose on which it seemed to be perched" [6]. Another exquisite invention of the period was a theatre eye-glass with a reservoir for an acrid composition that "made tears flow from the eyes" more effectively than the "darling Karamzin". There was a custom to take such glasses to "tearful comedies" as they called melodramas then. Seen now as a curiosity, those fanciful things were invented with the sole purpose of describing the indescribable. Such things are viewed only as an allegory, deeming it an acceptable convention that Virtue is a semi-naked lady with a lily or that a crowned column is an absolutely unambiguous representation of the sacrosanctity of the ruler and his clan. However, allegory had for so long been the living language of Ancien Régime culture ex contrario, that is, by dint of concreteness, with which an abstraction (Virtue) transformed into a tangible image.

\section{THE ICONOGRAPHY OF SENTIMENTALISM}

"...Did you ever see such a thing as a drawing of a muchness?" Lewis Carroll asked when describing three little sisters drawing things that begin with an $\mathrm{M}-$. Owing to the language of allegory, Ancien Régime art managed to do that for a long time. The question is how it was reflected in the culture of sentimentalism, which enriched traditional iconography with natural motifs.

In this sense a curious clue is offered by the well-known portrait of Gavrila R. Derzhavin done by Salvatore Tonci in 1801 (State Tretyakov Gallery), or rather by the chance to relate this portrait to several commentaries: Derzhavin's Ode To Tonci as a sort of portrait programme; the poet's comments on the ode, as concrete as any statement of his; and the text inscribed by the artist on his canvas. Derzhavin was known to be happy at the prospect of being painted by Tonci, who was famous not so much as a painter but as a Sentimentalist poet and philosopher - the "Italian Shaftesbury" - and was well received in the circle of the Derzhavin-Lvov-Kapnist families and friends. The legend that the Ode was written in response to Tonci's indecision whether to portray the poet Derzhavin uniformed as the Collegia of Commerce president, complete with orders, or with the attributes of a poet is hardly true. The philosopher of an artist and avowed critic of mythological allegories, Tonci was from the outset ready to produce something in a new taste. He presented Derzhavin "amidst Nature most harsh,/ In brutal cold, his soul afire / In shaggy hat and wrapped in furs", as Derzhavin had suggested in his ode, which he apparently started simultaneously with Tonci's work on the canvas and continued to polish up to 1808 , "To forge ahead, by Nature led alone / To brave all weathers, waters, rocks of flint" [7]. Explanations to the ode make it clear that the poet needs all of that in order - verbatim - "to show: first, that he became a poet almost without any schooling, by Nature alone; second, that in his service he had encountered many obstacles, but managed to overcome them through his character and without any patronage" [8]. True, in Tonci's portrait Derzhavin is not moving, but sitting stately, although in an uncomfortable landscape, where there is cold, and icy waters and a rock of flint. To avoid the meaning of his picture being misunderstood, the artist inscribed on it a maxim of his own make in Latin: Justitici in scopulo, restilo mens delphica in ortu Fingitur, in alba corque fides... (nive) that can be translated as follows: "Justice in the rock, prophetic mind in the bright dawn, pure heart and honesty in the whiteness of snow". (In the Ode: "so that I am kind to children / and by duty alone a ruthless judge to all".) In other words, both the sitter and the artist saw the natural landscape in the background as an allegorical composition, with natural (in the idiom of the period) forms serving as emblems. Hence the need for commentaries that would facilitate understanding of abstract ideas and notions.

There are fascinating versions of this portrait: another canvas that was sent to Irkutsk to merchant Sibiriakov, who had gifted Derzhavin, "the premier Russian poet", the furcoat and hat he had been portrayed in (legend has it that the portrait owed its appearance to that gift; Irkutsk Picture Gallery), and a pencil sketch made by Alexei Egorov after the portrait composition to serve as an illustration for the publication of Derzhavin's Anacreontic Odes (State Russian Museum). In both the visualisation of the "Prophetic Mind", as we now know, as "the bright dawn" was enhanced by a mythological figure with a trumpet, that is, in the understandable language of the emblemata as the allegorical link "prophet and path of glory". In the sketch Fame writing on the tablets of history occupied nearly half of the composition. In accordance with the then accepted practice of "improving the portrait", at Sibiriakov's request an anonymous artist added to the Irkutsk canvas a winged genius with the inscription "May God grant more of such" coming from its trumpet. That addition can no longer be seen. In the 1870 s it was cleared off and the exile artist Vronsky painted a view of Irkutsk instead (with that view the picture has survived to our day). This is but further proof that the natural pictures of sentimentalism existed in the classicist system of allegorical representation and that contemporaries perceived them as such.

\section{AlLEGORICAL ABCS EXTENDED}

This list can be extended in an interesting way, all the more so since Derzhavin and the history of the illustration of his Anacreontic poetry that became a sort of manifesto of Russian sentimentalist poetry offer copious material. The socalled Red (by the colour of its leather binding) or Catherine's Notebook with drawings by A.N. Olenin from the Public Library collection was presented to Catherine the Great in 1795 and the Green Notebooks (from the Pushkin House collection, with Anacreontic poetry forming part of the $3^{\text {rd }}$ Notebook) were compiled around 1805 [9]. In those manuscripts, verses have head- and tailpieces sometimes copied from Olenin's drawings and at times from later compositions of Alexei Egorov (with whom Derzhavin signed a contract for illustrating his poetry circa 1802; the State Russian Museum stores a whole block of those sketches [10]). Some of them were done by the young Ivan Ivanov, whose hand is seen in most of the drawings incorporated in the aforementioned manuscript. There are 
sheets without any text with variants of head- and tailpieces, most of them supplied with "programmes" of fairly allegorical nature (the Olenin compositions authored by himself while Egorov and Ivanov worked on Lvov's and Kapnist's programmes). Overall, it is a very interesting material yet to be analysed from the point of view of the evolution of the allegories of Russian sentimentalism. For instance, variants of the headpiece for the poem Ruins (elegy to the former glory of Tsarskoye Selo) demonstrate the transition from a mythological composition to a fairly natural view of ruins, in which only the winged wheel in the foreground hints at the didactic meaning of the underlying programme.

Derzhavin was very particular about the way his verses were illustrated (even though he did not live to see illustrated publications of his poetry). His well-known lines, "The poet's spirit may create, / It is the painter who breathes life into creations", are indicative in this respect. Derzhavin was not alone in his desire to see "life breathed" into the image created by the poet. It was not only a matter of illustrations but of the pictorialism of the literary "pictures born of the sensitive pen", or, to quote a latter-day student of sentimentalist prose, "pictorialism emerged as the main textforming principle" [11]. Scenes of nature in works of Karamzin, Izmailov or Muraviev easily come to mind. Be they inventive or intrusive, they not merely accompany the character's feelings but induce in him those feeling above all through memory. The walls of the Simonov Monastery, which keeps the memory of poor Lisa, Rostovskoye ozero (Lake of Rostov) by V. Izmailov, Aptekarsky ostrov by V. Popugaev, the St Makarius Monastery at Zholtye peski in Neschastnaya Margarita (Wretched Margarita) by an unknown author, a rose garden amidst four willows in Bednaia Khloe (Poor Chloe) by Karra-Kakuello-Gurji or Tiomnaia roshcha, Ili pamiatnik nezhnosti (Dark Grove, Or a Tenderness Monument) by P. Shalikov are above all memorable places arousing sensitivity.

\section{CONCLUSION}

It is a very intriguing twist provoking thoughts whether the sensitivity of sentimentalism is in fact the sensitivity of remembrance. This is something worth thinking about. Already at first glance, two fascinating consequences of the above hypothesis cannot be ignored. If it is true, the enlightened sensitivity of sentimentalism presupposes a prototype story that had already taken place and been registered by memory. This means that there is a gap, a distance that enables a concrete person to express his/her feelings in precedents already objectivised by cultural memory - something like Dido's faints or Penelope's fidelity, etc. - with which manifestations of personal feelings were identified directly irrespective of their depth and sincerity, irrespective of whether the tears were shed naturally or due to a smart eye-glass. All that matters is that the moment is appropriate. This threshold tangibly distinguishes the sensitivity of sentimentalism from personal feelings, to which man will succumb in subsequent periods, and what is more, lays bare the mechanics of sentimentalist poetics manifested in the literary genre of travels, among other things. A textbook example is Pisma russkogo puteshestvennika Karamzina (Letters of the Russian Traveller Karamzin), known for over a century to be an applique of fragments of the more authoritative literary writings of that period describing the highlights of the mentioned places (irrespective of claims against the quality and meaning of that indisputably original and highly substantive piece of writing).

That is one thing. Second, the remembrance mechanism that induces personal sensitivity reveals the nature of memory in sentimentalism that takes effect, as demonstrated earlier, within the framework of Ancien Régime cultures, that is, prior to reflection on time as existential. Memory obviously unfolded in sentimentalism not so much in the temporal as in the spatial perspective, like Kropotov's "landscape of my imagination" [12]. Hence the importance of memorable landmarks, whether a porcelain cup or a Pavlovsk park pavilion, that are nothing but souvenirs and commemorative tokens. By nature they are capable of representation (because a souvenir serves to visualise memories and feelings associated with it) and are decorative (because this type of visualisation brings into play the mechanism of textbook allegory that inherently strives to become an ornamental motif) and occasion-specific (as it is always associated with some concrete moment that provokes feelings and memories). This brings to mind H.-G. Gadamer, who studied the perfection of occasionality, decorativeness and the "ontological valence of the picture" as the decisive characteristic of pre-modernist cultures [13]. This also prompts an analogy with the polyphony of artistic forms, which was characteristic of art of the end of the century, when, as Eugene Lanceray remarked about the Gatchina Palace interior design, it seemed that all tastes and styles that manifested themselves in any way in the course of the $18^{\text {th }}$ century had "trooped together" by its end.

Anyhow, it is to be hoped that this angle of view has shed some light on the origin of souvenir culture and its significance in the poetics of sentimentalism. After all, it is thanks to memorable things that the newly discovered space of personified memory ceases to be a Terra incognita and comes across as a fanciful, yet observable and meaningful panorama.

\section{REFERENCES}

[1] Sablukov, N.A. "Zapiski" (Notes) // Tsareubiistvo (Regicide). Moscow, 1990, p. 59.

[2] Korndorf, A.S. "Mnemonic Programmes of Eighteenth-century Russian Imperial Residences. Memory Metamorphoses" in Memory as the Subject and Instrument of Art Studies. Moscow, 2016, pp. 157-175

[3] For instance, a déjeuner service with Pavlovsk views framed with rose wreathes made in 1807 of old blanks marked with Paul I cipher. State Russian Museum porcelain collection 1616, 1620, 1622.

[4] Russkaia starina, May 1882, pp. 319-76.

[5] See Sipovskaya, N.V. "Farfor v sisteme sentimentalnoi obraznosti" (Porcelain in Sentimental Imagery System) // Dom Burganova. Prostranstvo kultury. Moscow, No. 2, 2010.

[6] Kobeko, D. Cesarevitch Pavel Petrovich (1754-1796). Saint Petersburg, 1887, p. 217. 
[7] Derzhavin, G.R. To Tonci, in Derzhavin, G.R. Anakreonticheskie pesni (Anacreontic Songs). Literary Monuments series, Russian Academy of Sciences. Moscow: Nauka, 1987, p. 61.

[8] Explanations to Derzhavin's works as regards unclarities, proper names, allusions and other expressions the meaning of which is known only to the author, as well as the clarification of pictures associated with them and the anecdotes connected with their execution. Institute of Russian Literature (Pushkin House). Derzhavin's Archive, f. 91, No. 16. Cit. Ibid., p. 434

[9] Derzhavin's works with drawings presented to Catherine the Great (State Public Library); Derzhavin's Works, parts 1-4, 6. Institute of Russian Literature (Pushkin House). Derzhavin's Archive, f. 96, op. 1, Nos. 5-8, 10.

[10] State Russian Museum, r. 2700-2702.

[11] See Orlov, P.A. Russkii sentimentalizm (Russian Sentimentalism). Moscow, 1972.

[12] A. Kropotov's writings were published under that title in a separate book in 1803 .

[13] See Hans-Georg Gadamer. Wahrheit und Methode. Grundzuge ener philosophischen Hermeneutik. Tübingen, 1960. 